\title{
TUSSOCK GRASSLAND ASSOCIATIONS
}

S. H. Saxbyy, Agrostologist, Department of Agriculture,. Wellington.

\section{DISTRIBUTION OF THE TUSSOCK GRASSLANDS}

At the time colonisation commenced in New Zealand, about one hundred years ago, there were two main and distinct types of vegetation. First, there was the tall-growing association of forest trees, shrubs, and fern, which was confined in the main to the North Island and to the higher rainfall areas of the South Island. Second, there was the xerophytic grass-dominated association, which was present in the lower rainfall areas on the eastern side of the main divide of the South Island. This association was able to survive under the conditions of low rainfall, high summer temperatures, and low winter temperatures, and the constant desiccating winds. This grass association extended from high altitudes to sea level and was, in general, present in all areas where forest was unable to survive. A similar association was also present in the high altitudes of the central plateau of the North Island.

\section{NATURE OF THE TUSSOCK GRASSLANDS}

Though the tussock grasslands represent a distinct over-all vegetative association, they are very variable in composition, this variation depending on factors such as moisture, aspect, and soil fertility. There are, however, four grasses the dominance of which can divide the tussock country into as many fairly distinct types.

1. Snow grass (Danthonia flavescens). This tall growing grass thrives chiefly in the high altitudes, but in the southern parts of the South Island it descends to sea level. When allowed to grow unhindered snow grass forms almost pure associations in many areas. Where the association is not dense, however, many other plants are present. A common associate is the cotton plant (Celmisia spectabilis). The snow 


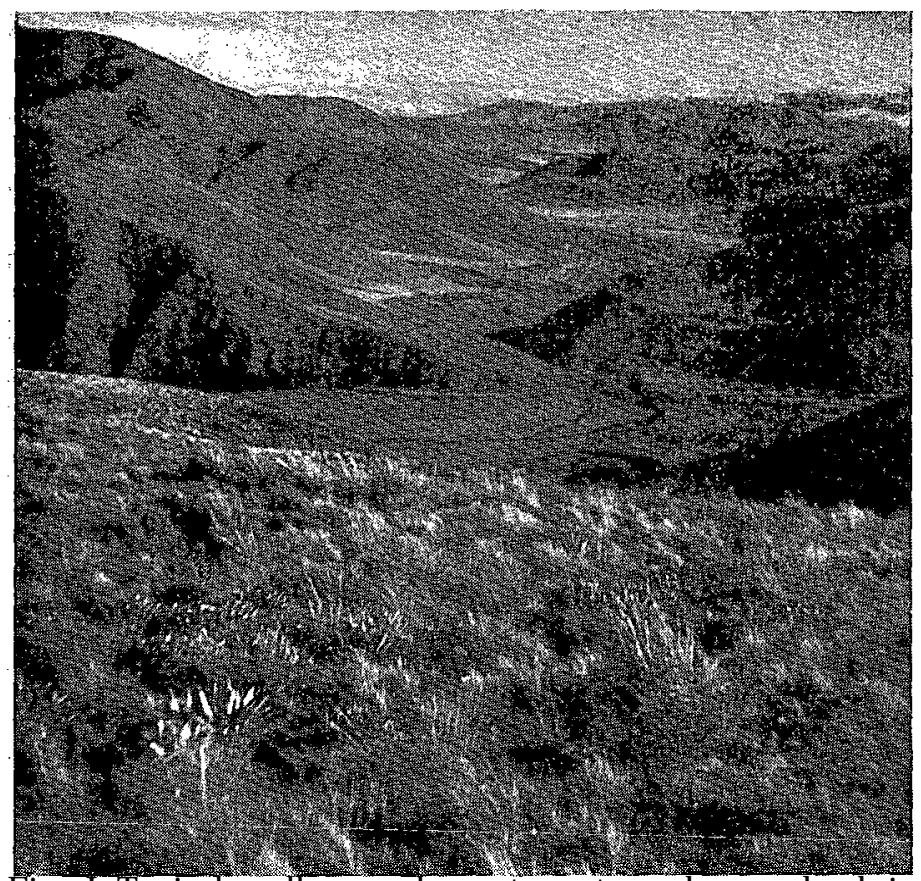

Fig. 1.-Typical well-covered montane tussock grassland in Canterbury. Snowgrass in foreground with hard tussock on lower levels.

gentian (Gentiana corymbifera) is also abundant in some areas. In very open associations the needleleafed heaths (Dracophyllum spp.), together with a number of herbs and grasses, are common

2. Hard Tussock (Festuca novae-xelandiae). This tussock, which is the most abundant and most droughtresisting of the indigenous tussock grasses, dominates very large areas of country ranging from sea level up to $4,000 \mathrm{ft}$. above sea level on sunny faces. It is usually associated with leached or slightly leached soils and is the dominant plant of the montane tussock grassland. Several other tussocks are often associated with hard tussock. Of these, silver tussock (Poa caespitosa), blue wheat grass (Agropyron scabrum), and blue tussock (Poa colensoi) are the most common. Matagowrie or wild Irishman (Discaria toumatou) is very plentiful on hard tussock country and is particularly abundant on loose shingly soils.

3. Silver tussock (Poa caespitosa). Though frequently associated with hard tussock, silver tussock 
is the dominant plant on the more moist areas and is the most common tussock on the higher rainfall areas in the lower country. Silver tussock grassland frequently verges on shrubby plant associations con-taining plants such as manuka (Leptospermum scoparium), bracken fern (Pteridium esculentum) and tutu (Coriaria spp).

4. Red tussock' (Danthonia raoulii). This large, tussock forms almost pure associations on cold, sour soils in districts with a relatively high rainfall. It was- particularly abundant on the plains and rolling country of Southland. It was also present on the water-logged soils of the higher altitude tussock grass-. land in Canterbury, and on the central plateau of the North Island. Flax (Phormium tenax) is often as-sociated with red tussock in the meandering sluggish streams and swampy hollows.

The four tussock grasses snow 'grass, hard tussock, silver tussock and red tussock were the dominant plants of relatively stable and distinct associations, each having been evolved under different soil or climatic conditions.

\section{THE IMPACT OF FARMING}

To New Zealand as a whole the tussock grasslands are of value for one purpose only, that is, the feeding of livestock. When settlement commenced it was found that this grassland provided good ready-made grazing, of value for the production of wool, which, at that time, was the country's main export. It was. also found that more sheep could be fed better if the tussock was burnt periodically. This burning not only removed the relatively useless and unpalatable top-hamper of growth, but encouraged young and fairly palatable growth to come away. This enabled more stock to be fed more adequately. Such a major alteration in the "way of living" of the tussock grasslands had important and far reaching effects in some areas. An additional alteration was the invasion by the rabbit in some areas. After a long period of unhindered development the grassland was suddenly assailed by fire and by grazing. Many plants failed to survive this change and gave way to others that could. Grasses usually least fitted to survive close continuous. grazing are those of a tall growing habit, whose crowns. require a shading of top growth. Most of the tussock grasses are unable to survive continuous defoliation. 
The over-all effect of farming on the tussock grassland has been a trend towards the replacement of a stable tall-growing vegetation, that was unhampered in its growth, by a stable mat-forming vegetation that is able to survive the impact of farming. Under existing methods of farming this change to stability is inevitable' and will continue. The nature of the new associations vary considerably from one location to another. In some areas the dominant plants are unpalatable ; in others they are palatable, and in some areas unpalatable shrubby plants have tended to dominate.

\section{CHANGES IN TUSSOCK GRASSLAND ASSOCIATIONS}

One hundred years of farming have resulted in some marked changes in the tussock grassland associations. They may be classified as follows:-

\section{Slightly Altered.}

Largely owing to favourable climatic conditions considerable areas of tussock country have not altered greatly. The main change has been the killing out of some tussock, particularly snow grass, and its replacement to some extent with hard tussock and blue tussock. Associated with this change has been the ingress of low-growing, free-seeding plants such as browntop (A gros tis tenuis), Yorkshire fog (Holcus lanatus), sweet vernal (Anthoxanthum odoratum), and catsear (Hypochaeris radicata). A combination of suitable climatic conditions, light stocking with sheep, and an absence of rabbits has tended to favour the dominance of the tussock-dominated associations.

\section{Major alterations under high rainfall.}

In some of the higher rainfall areas where tussock grassland bounded rain forest or beech forest, considerable changes have taken place. Typical locations are in the vicinity of Lake Te Anau and the nearcoastal areas ad joining Dunedin. Burning of the tussock and grazing by sheep and to some extent by rabbits, have resulted in the elimination of much of the tussock and its replacement by other plants. Two distinct associations have developed. Where the fertility was relatively high, as in the case of country carrying silver tussock, plants such as brown top, sweet vernal, stunted white clover, dogstail, and some ryegrass have formed an association that is relatively stable and more productive than the tussock association which it replaced. 
On the other hand, where the fertility was low, :as is the case with much of the hard tussock country, the tussock has been replaced very largely by shrubby, shade-producing, unpalatable plants such as manuka, gorse, blackberry, broom, tutsan, and bracken fern. Repeated burning of these new associations merely encourages, their perpetuation.

\section{Major alterations under low rainfall.}

In some of the lower rainfall areas, such as are present in parts of Marlborough, the southern end of the Mackenzie Country, and much of the low altitude country of Central Otago, large areas of tussock

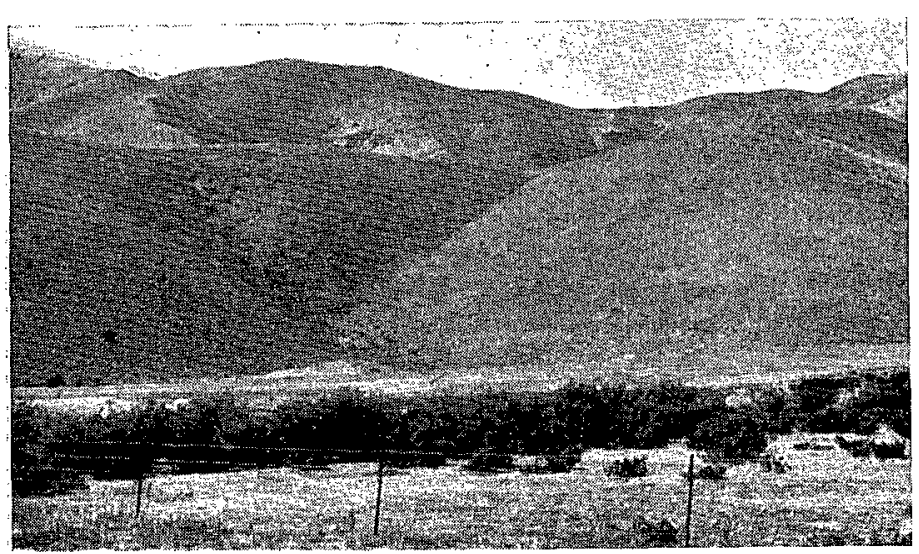

Fig. IL-Depleted tussock grassland in Central Otago. On left, tussock surviving on shady face. On right, scabweed has replaced tussock on sunny exposed face.

have disappeared as the result of farming. Before farming commenced the vegetation was comparatively stable, but because of the very low rainfall its stability was easily upset by burning and by grazing by sheep and hordes of rabbits. The tussock association was replaced by another association dominated by the mat forming, unpalatable, xerophytic plant scabweed (Raoulia lutescens). This new association is relatively stable and is unlikely to be modified further, except as the result of erosion by wind and water.

\section{Alterations in the red tussock association.}

Most types of tussock association have in one area or another been eliminated by the use of the plough. The most striking alteration of this nature that has been made is that on the red tussock country of Southland. Thousands of acres of red tussock have been 
replaced by first-class lamb-fattening and dairying pastures. Areas that have not been changed by the plough are in parts being modified as the result of the ingress of tall-growing plants such as gorse and, to some extent, manuka and broom. In general, however, the red tussock associations have been altered comparatively little, except by the plough.

\section{TUSSOCK GRASSLAND PROBLEMS}

Pasture improvement in most parts of the country aims at establishing and maintaining a high-producing legume. On the one time bush-clad hill country of the North Island the introduction of a legume is usually both possible and profitable.

It is, however, necessary to consider carefully whether or not a legume should be introduced into unploughable tussock country. That it is possible has been demonstrated on a number of occasions. It is, however, doubtful if it is advisable. It is unlikely to be profitable, as considerable quantities of fertiliser and, in many areas, lime as well, together with seed, would have to be applied to maintain the legume. The return in terms of extra stock carried would have to be very much greater than a doubling of carrying capacity when it is understood that tussock country carries from 1 sheep to 4 acres to 1 sheep to 10 acres.

The most important reason for doubting' the advisability of introducing a high-producing legume into the tussock country is the effect that this would have on the grassland itself. Tussock grassland at present is composed of a mixture of tall- and short-growing plants. Such a mixture is desirable for two reasons. First, it provides both feed and shelter for stock. The tussock performs an additional function in breaking the carpet of snow after a snowfall much more rapidly than will a mat type of vegetation. Second, the tussock is valuable in providing shade and shelter, both of which assist seedlings of the palatable and valuable plants to establish.

With the introduction of a high-producing legume the nature of an association changes, the fertility is raised, more stock are carried, and the tussocks disappear slowly. In the event of a cessation of topdressing the legume will become moribund and the pasture will be dominated by mat-forming plants, the commonest of which is browntop. The change that is likely to take place is, therefore, from a tussock-dominated association to a browntop-dominant 
association, which, in the opinion of many runholders, is undesirable,

For these reasons, therefore, the main problem in tussock grassland improvement is not one of introducing a high-producing legume, but of increasing the volume of palatable grass and at the same time maintaining the tussock as a dominant.

\section{TUSSOCK GRASSLAND IMPROVEMENT}

The improvement of tussock grassland must be related to changes that have taken place and to the vegetation that is present now. There is no major problem present in those areas where the association has been modified only slightly. The association there is relatively stable, the carrying capacity is stable, and rabbits are absent. Although experimental work is still being- conducted, there is no evidence that the surface sowing of grasses on hard tussock country is warranted. There is, however, evidence to show that the sowing of cocksfoot on silver tussock country is giving good results.

On the low rainfall areas, where tussock has been replaced by scabweed, evidence gathered from experiments conducted over the last 40 years or so shows that much of the country can be reclothed with a useful vegetation.

As investigations continue additional useful plants may be found, but at the present time the problem is not so much what to sow as how to establish it. Sowing seed on an undisturbed surface has been disappointing, better strikes always being obtained on ground that has been disturbed. Of the many plants tried out, the following show promise of being valuable under certain conditions :-

Tall oat grass (Arrhenatherum elatius).

Blue wheat grass (Agropyron scabrum).

Phalaris tuberosa.

Cocksfoot (Dactylis glomerata).

Tall fescue (Festuca arundinacea) .

Kentucky bluegrass (Poa pratensis).

Yarrow (Achillea millefolium).

Danthonia pilosa.

Sheep's burnet (Poterium sanguisorba).

Brachypodium phoenicoides.

Lucerne (Medicago sativa). 


\section{WEEDS}

Weeds are a problem of almost all grassland associations, their presence indicating that the existing conditions are more suitable for them than they are for the more desirable plants. The basic principle of weed control is one of altering the conditions to such an extent that the useful plants are encouraged at the expense of the useless ones.

Tussock grassland associations have their own weed populations and problems. It is necessary to appreciate that many plants which are regarded as weeds of lowland country are desirable plants in tussock grassland. For instance catsear, viper's bugloss, sorrel, Californian thistle, winged thistle, dyer's weed and eschscholtzia are all eaten to a greater or lesser degree by sheep. In some areas at least they must therefore be of value when the virtual absence of accompanying palatable grasses is taken into account.

There are, however, a number of weeds of tussock grassland that present appreciable problems. Sweet briar, gooseberry, matagowrie, manuka, tutsan, and, more recently, nassella tussock have proved to be troublesome weeds in various tussock associations, Their presence, as important constituents in the associations, indicates that the existing conditions of plant 'and animal competition are favourable to their increase. Until recently, St. John's wort was regarded as one of the major weeds in some areas because it could not be controlled by grazing. With the introduction of an insect capable of defoliating St. John's wort, its significance as a weed is decreasing.

In the revegetating of the depleted country it must be realised that spelling, which is essential for the establishment and maintenance of the desirable plants, may also encourage the growth of the undesirable plants as well. For example, both sweet briar and matagowrie, have, in a comparatively few years, become firmly established on land that has been spelled. Tussock grassland weeds present a greater problem than do those of higher value land because the cost of their eradication is so high in relation to the productive value of the land.

\section{CONCLUSION}

Almost one half of New Zealand's grassland is tussock grassland. The impact of one hundred years of farming has left its marks and scars which, in some 
areas, are conspicuous. One should, however, wonder, not at the marks that have been made, but at the many marks that could have been made but which have not been made. Many of the tussock grassland associations are now stable and valuable. With the runholders' hundred years of experience behind them, these should remain so.

For the depleted land there is more than a glimmering of hope. Good progress has been made with solving of the problem of revegetation and there is some evidence that the day on which the rabbit will be brought under control is coming nearer.

The tussoek grasslands have produced vast quantities of wool in the past and there is no reason why. they should not continue to do so provided always that they are given the treatment which will maintain them as grassland associations. 